\author{
УДК 332.341 .1 \\ Ковальська Л.Л., д.е.н., професор \\ Оксенюк К.І., к.е.н., доцент \\ Луцького національного технічного університету
}

\title{
СТАН ТА ТЕНДЕНЦІЇ ІННОВАЦІЙНОГО РОЗВИТКУ РЕГІОНІВ ДЕРЖАВИ
}

У статті проведено дослідження стану та тенденцій інноваційного розвитку регіонів держави. Проаналізовано передумови та результати інноваційного розвитку регіону. Здійснено оцінку тенденцій розвитку передумов за такими напрямами: кількість працівників, задіяних у виконанні наукових досліджень, чисельність організацій, які здійснювали наукові розробки і дослідження, обсяг фінансування внутрішніх витрат на виконання наукових досліджень, кількість аспірантів та докторантів. Проведено оцінку результатів інноваційного розвитку за системою показників: кількість підприємств, що займаються інноваційною діяльністю, кількість впроваджених нових технологічних процесів на промислових підприємствах, обсяг реалізованої інноваційної продукції, кількість впроваджених інновацій. Виявлено позитивні та негативні темпи росту передумов та результатів інноваційного розвитку регіонів держави.

Ключові слова: регіон, інноваційний розвиток, передумови інноваційного розвитку, результати інноваційного розвитку, інновація, стан, тенденції, інноваційний продукт, інноваційна діяльність.

Kovalska L., Okseniuk K.

\section{STATE AND TRENDS OF INNOVATIONAL DEVELOPMENT OF REGIONS OF THE STATE}

The article analyzes the state and trends of innovation development of the regions of the state. The preconditions and results of innovative development of the region are analyzed. The estimation of trends in the development of preconditions for the following areas: the number of employees involved in the implementation of research and development, the number of organizations that carried out research and development, the amount of funding for internal spending on research, the number of postgraduate students and doctoral students. An evaluation of the results of innovation development in the system of indicators was made: the number of enterprises engaged in innovation activity, the number of new technological processes implemented at industrial enterprises, the volume of implemented innovative products, the number of innovations introduced. Positive and negative growth rates of the preconditions and results of innovative development of the regions of the state are revealed.

Key words: region, innovation development, preconditions of innovative development, results of innovation development, innovation, state, trends, innovation product, innovation activity.

Ковальская Л.Л., Оксенюк К.И.

\section{СОСТОЯНИЕ И ТЕНДЕНЦИИ ИННОВАЦИОННОГО РАЗВИТИЯ РЕГИОНОВ ГОСУДАРСТВА}

В статье проведено исследование состояния и тенденций инновационного развития регионов страны. Проанализированы предпосылки и результаты инновационного развития региона. Осуществлена оценка тенденций развития предпосылок по следующим направлениям: количество работников, задействованных в выполнении научных исследований и разработок, численность организаций, осуществляющих научные разработки и исследования, объем финансирования внутренних затрат на выполнение научных исследований, количество аспирантов и докторантов. Проведена оценка результатов инновационного развития по системе показателей: количество предприятий, занимающихся инновационной деятельностью, количество внедренных новых технологических процессов на промышленных предприятиях, объем реализованной инновационной продукции, количество внедренных инноваций. Выявлены положительные и отрицательные темпы роста предпосылок и результатов инновационного развития регионов страны.

Ключевые слова: регион, инновационное развитие, предпосылки инновационного развития, результаты инновационного развития, инновация, состояние, тенденции, инновационный продукт, инновационная деятельность. 
Постановка проблеми у загальному вигляді та їі зв'язок із важливими науковими чи практичними завданнями. В умовах посилення процесів інтеграції регіонів України у міжнародний економічний простір, актуалізуються питання формування інноваційної моделі розвитку економіки держави, де головною рушійною силою економічного зростання виступають інновації. Регіони держави повинні прагнути до забезпечення інноваційної активності через формування нових технологічних укладів економіки, формування та ефективного використання інтелектуального капіталу регіону, ефективного здійснення інноваційного підприємництва, забезпечення синергії в системі «наука-виробництво» тощо. Все це потребує детального дослідження стану та тенденцій інноваційного розвитку регіонів задля виявлення проблем та можливостей забезпечення інноваційного зростання регіонів держави.

Аналіз останніх досліджень і публікацій, в яких започатковано розв'язання даної проблеми. Проблемам інноваційного розвитку регіонів держави приділяється досить багато уваги, в тому числі не залишаються осторонь й питання щодо оцінки стану та тенденцій інноваційного розвитку. Серед таких публікацій доцільно виділити роботи 3.Варналія [1], В.Воротіна [2], Т.Васильців [2], В.Волошин [2], В.Денисюка [3], Т.Мілевської [4], Н.Рудь [5], Л.Федулової [6, 7, 8], інших. Проте, проблематика інноваційного розвитку регіону і надалі залишається актуальною, що потребує подальших поглиблених досліджень.

Цілі статті. Проведемо оцінку стану та тенденцій інноваційного розвитку регіонів держави.

Виклад основного матеріалу дослідження 3 повним обгрунтуванням отриманих наукових результатів. Оцінювати стан та тенденції інноваційного розвитку регіону пропонується за такими напрямами: оцінка передумов інноваційного розвитку регіону та оцінка результатів інноваційного розвитку регіону. Система показників оцінки за даними напрямами наведена у таблиці 1.

Таблиця 1.

Показники оцінки стану та тенденцій інноваційного розвитку регіону

\begin{tabular}{|l|l|}
\hline \multicolumn{1}{|c|}{ Напрями оцінки } & \multicolumn{1}{|c|}{ Показники } \\
\hline & Кількість працівників, задіяних у виконанні наукових \\
Оцінка передумов інноваційного & досліджень і розробок, чисельність організацій, які \\
розвитку регіону & здійснювали наукові розробки і дослідження, фінансування \\
& $\begin{array}{l}\text { внутрішніх витрат на виконання наукових досліджень, } \\
\text { кількість аспірантів, що виконують науково-дослідні роботи, } \\
\text { кількість докторантів, що виконують науково-дослідні роботи }\end{array}$ \\
\hline $\begin{array}{l}\text { Оцінка результатів інноваційного } \\
\text { розвитку регіону }\end{array}$ & $\begin{array}{l}\text { Кількість підприємств, що займаються інноваційною } \\
\text { діяльністю, кількість впроваджених нових технологічних }\end{array}$ \\
& процесів на промислових підприємствах, обсяг реалізованої \\
& інноваційної продукції, кількість впроваджених інновацій
\end{tabular}

За наведеною системою показників проведемо оцінку стану та тенденцій інноваційного розвитку регіону. Аналіз та оцінка передумов інноваційного розвитку регіонів держави наведена у таблиці 2. Отож, можемо спостерігати нестійку динаміку показників, що характеризують передумови інноваційного розвитку регіону. 
Таблиця 2.

Аналіз та оцінка передумов інноваційного розвитку регіонів держави

\begin{tabular}{|c|c|c|c|c|c|c|c|c|c|c|c|c|c|c|c|}
\hline \multirow[t]{2}{*}{ Регіони } & \multicolumn{3}{|c|}{$\begin{array}{c}\text { Кількість працівників, } \\
\text { задіяних у виконанні } \\
\text { наукових досліджень і } \\
\text { розробок }\end{array}$} & \multicolumn{3}{|c|}{$\begin{array}{c}\text { Чисельність } \\
\text { організацій, які } \\
\text { здійснювали наукові } \\
\text { розробки і } \\
\text { дослідження } \\
\end{array}$} & \multicolumn{3}{|c|}{$\begin{array}{c}\text { Фінансування внутрішніх витрат на } \\
\text { виконання наукових досліджень }\end{array}$} & \multicolumn{3}{|c|}{$\begin{array}{c}\text { Кількість аспірантів, що } \\
\text { виконують науково- } \\
\text { дослідні роботи }\end{array}$} & \multicolumn{3}{|c|}{$\begin{array}{c}\text { Кількість докторантів, } \\
\text { що виконують } \\
\text { науково-дослідні } \\
\text { роботи }\end{array}$} \\
\hline & 2015 & 2016 & 2017 & 2015 & 2016 & 2017 & 2015 & 2016 & 2017 & 2015 & 2016 & 2017 & 2015 & 2016 & 2017 \\
\hline $\begin{array}{l}\text { Автономна } \\
\text { республіка Крим }\end{array}$ & & & & & & & & & & & & & & & \\
\hline Вінницька & 484 & 704 & 627 & 19 & 20 & 22 & 26912,9 & 39473,3 & 44803,0 & 679 & 683 & 599 & 29 & 26 & 22 \\
\hline Волинська & 188 & 258 & 314 & 10 & 10 & 9 & 13838,9 & 13604,1 & 18414,9 & 388 & 330 & 279 & 17 & 15 & 11 \\
\hline Дніпропетровська & 9604 & 9675 & 8954 & 58 & 58 & 54 & 1366037,9 & 1843750,8 & 2261934,6 & 1380 & 1313 & 1299 & 76 & 64 & 66 \\
\hline Донецька & 2134 & 217 & 238 & 20 & 15 & 18 & 165773,6 & 18902,8 & 13244,9 & 339 & 274 & 254 & 24 & 18 & 19 \\
\hline Житомирська & 266 & 368 & 410 & 9 & 9 & 9 & 16085,4 & 21360,5 & 28098,6 & 287 & 244 & 224 & 21 & 17 & 18 \\
\hline Закарпатська & 617 & 678 & 562 & 10 & 9 & 8 & 38851,1 & 46430,0 & 55241,8 & 314 & 359 & 425 & 9 & 17 & 20 \\
\hline Запорізька & 4194 & 4203 & 4216 & 26 & 30 & 31 & 500291,5 & 712401,9 & 914062,4 & 890 & 848 & 909 & 77 & 100 & 81 \\
\hline Івано-Франківська & 402 & 524 & 580 & 18 & 17 & 17 & 16746,7 & 20325,8 & 28051,2 & 549 & 505 & 488 & 25 & 35 & 39 \\
\hline Київська & 2199 & 1833 & 1805 & 26 & 28 & 30 & 194165,8 & 274177,9 & 299219,3 & 388 & 347 & 356 & 22 & 24 & 25 \\
\hline Кіровоградська & 441 & 480 & 503 & 15 & 15 & 15 & 57286,7 & 74614,5 & 75619,7 & 176 & 169 & 126 & 10 & 10 & 10 \\
\hline Луганська & 319 & 369 & 350 & 17 & 14 & 15 & 27323,9 & 23577,7 & 29332,4 & 381 & 290 & 243 & 32 & 29 & 25 \\
\hline Львівська & 4274 & 4648 & 4680 & 68 & 73 & 75 & 272127,6 & 264845,5 & 365997,1 & 2445 & 2182 & 2041 & 133 & 151 & 133 \\
\hline Миколаївська & 2212 & 2150 & 2268 & 25 & 25 & 26 & 299326,7 & 392583,5 & 349345,2 & 236 & 205 & 174 & 20 & 25 & 21 \\
\hline Одеська & 3066 & 3384 & 3003 & 49 & 47 & 48 & 201741,9 & 237456,8 & 270263 & 2035 & 1738 & 1674 & 92 & 79 & 83 \\
\hline Полтавська & 951 & 1302 & 1181 & 20 & 21 & 22 & 42574,5 & 55845,0 & 65967,7 & 561 & 498 & 497 & 24 & 30 & 28 \\
\hline Рівненська & 190 & 327 & 378 & 12 & 11 & 11 & 9317,2 & 9327,1 & 13723,8 & 281 & 274 & 269 & 8 & 6 & 7 \\
\hline Сумська & 1801 & 2857 & 2081 & 15 & 16 & 16 & 121238,0 & 129682,3 & 160696,5 & 592 & 524 & 596 & 32 & 32 & 30 \\
\hline Тернопільська & 221 & 383 & 361 & 11 & 13 & 13 & 10680,2 & 14052,4 & 19200,1 & 439 & 392 & 455 & 24 & 27 & 31 \\
\hline Харківська & 17127 & 16474 & 14851 & 166 & 160 & 149 & 1920618,1 & 2063160,8 & 2399423,8 & 3420 & 3198 & 3168 & 225 & 220 & 212 \\
\hline Херсонська & 574 & 683 & 732 & 16 & 20 & 21 & 33610,4 & 48804,6 & 73601,9 & 324 & 391 & 364 & 25 & 29 & 30 \\
\hline Хмельницька & 175 & 321 & 380 & 8 & 8 & 8 & 15564,1 & 12959,2 & 17510,0 & 394 & 390 & 411 & 26 & 27 & 24 \\
\hline Черкаська & 871 & 780 & 705 & 20 & 20 & 20 & 99478,3 & 118405,2 & 97350,6 & 403 & 360 & 346 & 37 & 34 & 29 \\
\hline Чернівецька & 545 & 837 & 809 & 20 & 19 & 18 & 45436,6 & 61275,9 & 68333,9 & 268 & 224 & 205 & 29 & 26 & 18 \\
\hline Чернігівська & 665 & 723 & 699 & 15 & 15 & 14 & 50885,2 & 41902,0 & 44296,3 & 208 & 196 & 203 & 7 & 15 & 20 \\
\hline м.Київ & 48078 & 43734 & 43587 & 305 & 299 & 294 & 5455976,3 & 4991777,9 & 5665559,7 & 11110 & 10029 & 9181 & 797 & 736 & 644 \\
\hline м.Севастополь & & & & & & & & & & & & & & & \\
\hline
\end{tabular}

Примітка: * - дані відсутні

Складено за даними $[9,10]$ 
Перш за все, проведемо оцінку кількості організацій, що здійснювали наукові розробки та дослідження, а також кадрового потенціалу підприємств, тобто працівників, задіяних у виконанні наукових досліджень і розробок, оскільки саме від них залежить подальший поступ науки і техніки, що дозволяє забезпечити конкурентоспроможність регіонів України та сформувати інноваційну модель їх розвитку $[11,12]$. Найбільша кількість організацій, що здійснювали наукові розробки та дослідження протягом аналізованого періоду була зосереджена у Дніпропетровській, Львівській, Одеській, Харківській областях та м.Києві. Відповідно тут і зосереджена найбільша кількість фахівців, що виконують наукові дослідження і розробки та фахівці вищої кваліфікації. М.Київ, Дніпропетровська, Харківська та Львівська області виступають лідерами за кількістю таких фахівців. Найменше їх було у Волинській, Луганській, Рівненській, Тернопільській областях. Слід відмітити, що різними є і темпи росту даних показників. Так, лише у Вінницькій, Запорізькій, Киӥвській, Львівській, Тернопільській, Херсонській області були позитивні темпи росту кількості організацій, що здійснювали наукові розробки та дослідження; в решта регіонах держави їх кількість зменшується, що негативно впливає на наявні потенційні можливості регіонів щодо продукування інновацій та забезпечення їх інноваційної активності. Натомість дещо кращою $\epsilon$ динаміка кількості працівників, задіяних у виконанні наукових досліджень і розробок. Така позитивна динаміка характерна для Вінницької, Волинської, Житомирської, ІваноФранківської, Кіровоградської, Полтавської, Рівненської, Тернопільської. Хмельницької та Чернівецької областей.

Фінансування внутрішніх витрат на виконання наукових досліджень з року в рік зростають в усіх регіонах держави за винятком Донецької (темп росту 0,08), Черкаської (темпи росту 0,98 ) та Чернігівської (темпи росту 0,87 ) областей. Проте, досить низьким рівень фінансування наукових досліджень був у Волинській, Донецькій, Житомирській, Івано-Франківській, Луганській, Рівненській, Тернопільській та Хмельницькій областях, що не дозволяє їм в повній мірі здійснювати фундаментальні та прикладні дослідження, освоювати нові технології та виробництва, випускати інноваційну продукцію тощо. Слід також відмітити, що протягом 2015-2017 років практично у всіх регіонах держави спостерігається негативна тенденція щодо кількості аспірантів та докторатів, що свідчить про зниження кадрового потенціалу фахівців вищої кваліфікації. Виняток складають такі регіони як Закарпатська, Івано-Франківська (лише докторантів), Київська (лише докторантів), Полтавська (лише докторантів), Тернопільська та Херсонська області. Таким чином, бачимо, що регіони держави мають різні потенційні можливості щодо забезпечення інноваційного розвитку. Ці можливості диференціюються залежно від обсягів фінансування інноваційної діяльності, кількості наукових кадрів, кількості організацій, що займаються науковими розробками, кількості аспірантів та докторантів тощо. Водночас, володіючи такими можливостями не кожен регіон держави ефективно їх використовує, що дає змогу отримати різні результати інноваційного розвитку. Аналіз та оцінка результатів інноваційного розвитку регіонів держави наведена у таблиці 3.

Розглядаючи результати, слід відмітити негативну тенденцію, пов'язану iз зменшенням обсягів реалізованої інноваційної продукції практично по усіх регіонах держави. Лише, у Вінницькій, Запорізькій, Київській, Кіровоградській, Миколаївській, Херсонській, Черкаській та Чернігівській областях позитивні темпи росту обсягів реалізованої інноваційної продукції. Причому, досить високі темпи росту спостерігаються у Миколаївській $(5,86)$ та Чернігівській $(3,6)$ областях, що свідчить про значне підвищення рівня їх інноваційного потенціалу.

Найбільша кількість впроваджених нових технологічних процесів та інноваційних видів продукції спостерігалася на підприємствах Дніпропетровської (107 та 84 од.), Запорізької (142 та 319 од.), Сумської (225 та 217 од.), Харківської (230 та 396 од.) областей та м.Києва (549 та 199 од). 
Таблиця 3.

Аналіз та оцінка результатів інноваційного розвитку регіонів держави

\begin{tabular}{|c|c|c|c|c|c|c|c|c|c|c|c|c|c|c|}
\hline \multirow[t]{2}{*}{ Регіони } & \multicolumn{3}{|c|}{$\begin{array}{c}\text { Кількість підприємств, } \\
\text { що займаються } \\
\text { інноваційною } \\
\text { діяльністю }\end{array}$} & \multicolumn{3}{|c|}{$\begin{array}{c}\text { Кількість впроваджених } \\
\text { нових технологічних } \\
\text { процесів }\end{array}$} & \multicolumn{2}{|c|}{$\begin{array}{c}\text { Обсяг реалізованої } \\
\text { інноваційної продукції }\end{array}$} & \multicolumn{3}{|c|}{$\begin{array}{c}\text { Кількість впроваджених } \\
\text { інноваційних видів } \\
\text { продукції }\end{array}$} & \multicolumn{3}{|c|}{ Патенти на винаходи } \\
\hline & 2015 & 2016 & 2017 & 2015 & 2016 & 2017 & 2015 & 2017 & 2015 & 2016 & 2017 & 2015 & 2016 & 2017 \\
\hline $\begin{array}{l}\text { Автономна } \\
\text { республіка Крим* }\end{array}$ & & & & & & & & & & & & & & \\
\hline Вінницька & 22 & 23 & 24 & 26 & 22 & 15 & 192387,0 & 454738,6 & 69 & 63 & 52 & 25 & 34 & 30 \\
\hline Волинська & 11 & 14 & 17 & 13 & 12 & 8 & 383598,6 & 66820,5 & 8 & 8 & 7 & 4 & 9 & 8 \\
\hline Дніпропетровська & 43 & 47 & 51 & 77 & 89 & 107 & 1145528,3 & 297806,2 & 150 & 110 & 84 & 161 & 135 & 132 \\
\hline Донецька & 17 & 19 & 22 & 20 & 45 & 69 & 4591841,2 & 3301952,6 & 153 & 134 & 101 & 72 & 30 & 40 \\
\hline Житомирська & 27 & 25 & 23 & 20 & 17 & 13 & 372263,7 & 155944,9 & 13 & 16 & 20 & 13 & 14 & 8 \\
\hline Закарпатська & 11 & 12 & 12 & 7 & 7 & 7 & 583169,7 & 358075,8 & 9 & 9 & 8 & 33 & 25 & 14 \\
\hline Запорізька & 45 & 44 & 42 & 124 & 134 & 142 & 3162297,1 & 4041214,5 & 397 & 365 & 319 & 42 & 38 & 45 \\
\hline Івано-Франківська & 23 & 25 & 28 & 50 & 45 & 23 & 241973,4 & 105412,0 & 117 & 115 & 109 & 24 & 19 & 30 \\
\hline Київська & 43 & 41 & 37 & 39 & 39 & 38 & 618814,9 & 770553,1 & 97 & 110 & 116 & 38 & 42 & 42 \\
\hline Кіровоградська & 22 & 23 & 24 & 19 & 17 & 16 & 354667,9 & 405582,7 & 51 & 44 & 36 & 9 & 5 & 5 \\
\hline Луганська & 7 & 7 & 7 & 21 & 18 & 4 & 373174,1 & 13130,9 & 14 & 13 & 11 & 24 & 9 & 7 \\
\hline Львівська & 61 & 55 & 48 & 49 & 45 & 41 & 1193855,9 & 763079,4 & 251 & 225 & 247 & 71 & 68 & 53 \\
\hline Миколаївська & 22 & 24 & 25 & 13 & 18 & 29 & 71192,7 & 417342,6 & 28 & 22 & 19 & 31 & 28 & 18 \\
\hline Одеська & 32 & 34 & 36 & 26 & 35 & 50 & 544420,2 & 157570,2 & 58 & 55 & 53 & 98 & 88 & 88 \\
\hline Полтавська & 27 & 27 & 27 & 34 & 33 & 31 & 1938551,4 & 243180,2 & 96 & 91 & 86 & 13 & 12 & 14 \\
\hline Рівненська & 12 & 10 & 8 & 9 & 9 & 8 & 67324,7 & 9266,5 & 7 & 7 & 6 & 4 & 5 & 5 \\
\hline Сумська & 22 & 23 & 24 & 185 & 221 & 225 & 1751880,2 & 601874,6 & 177 & 201 & 217 & 13 & 10 & 9 \\
\hline Тернопільська & 16 & 19 & 25 & 32 & 56 & 78 & 249303,3 & 126930,5 & 580 & 135 & 39 & 6 & 11 & 9 \\
\hline Харківська & 97 & 105 & 111 & 212 & 220 & 230 & 2742424,4 & 2515861,7 & 208 & 279 & 396 & 211 & 222 & 203 \\
\hline Херсонська & 19 & 17 & 15 & 25 & 25 & 24 & 175410,2 & 287619,7 & 41 & 56 & 80 & 12 & 12 & 10 \\
\hline Хмельницька & 18 & 15 & 8 & 9 & 8 & 7 & 127076,3 & 27769,1 & 24 & 18 & 7 & 4 & 2 & 1 \\
\hline Черкаська & 25 & 29 & 32 & 15 & 25 & 30 & 289705,7 & 583087,7 & 50 & 52 & 53 & 9 & 5 & 8 \\
\hline Чернівецька & 9 & 9 & 8 & 15 & 14 & 12 & 99981,9 & 46313,1 & 31 & 28 & 25 & 8 & 2 & 6 \\
\hline Чернігівська & 14 & 14 & 10 & 35 & 55 & 75 & 95927,5 & 345378,5 & 56 & 65 & 97 & 4 & 4 & 5 \\
\hline м.Київ & 78 & 80 & 95 & 152 & 550 & 549 & 1683322,6 & 1617739,3 & 451 & 350 & 199 & 569 & 437 & 425 \\
\hline м.Севастополь* & & & & & & & & & & & & 9 & 2 & 3 \\
\hline
\end{tabular}

Примітка: * - дані відсутні

Складено за даними $[9,10]$ 
Таблиця 4.

Групування регіонів держави за темпами росту передумов та результатів інноваційного розвитку

\begin{tabular}{|c|c|c|c|}
\hline & & \multicolumn{2}{|c|}{ Темпи росту } \\
\hline & & позитивні & негативні \\
\hline \multirow{5}{*}{ 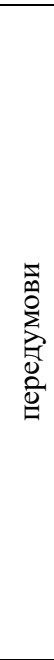 } & $\begin{array}{l}\text { Кількість працівників, задіяних } \\
\text { у виконанні наукових } \\
\text { досліджень і розробок }\end{array}$ & $\begin{array}{c}\text { Вінницька, Волинська, Житомирська, Запорізька, Івано-Франківська, } \\
\text { Кіровоградська, Луганська, Львівська, Миколаївська, Полтавська, } \\
\text { Рівненська, Сумська, Тернопільська, Херсонська, Хмельницька, } \\
\text { Чернівецька, Чернігівська } \\
\end{array}$ & $\begin{array}{c}\text { Донецька, Дніпропетровська, Закарпатська, Київська, Одеська, } \\
\text { Харківська, Черкаська, м.Київ }\end{array}$ \\
\hline & $\begin{array}{l}\text { Чисельність організацій, які } \\
\text { здійснювали наукові розробки і } \\
\text { дослідження }\end{array}$ & $\begin{array}{c}\text { Вінницька, Житомирська, Запорізька, Київська, Кіровоградська, } \\
\text { Львівська, Миколаївська, Полтавська, Сумська, Тернопільська, } \\
\text { Херсонська, Хмельницька, Черкаська, }\end{array}$ & $\begin{array}{c}\text { Волинська, Донецька, Дніпропетровська, Закарпатська, Івано- } \\
\text { Франківська, Луганська, Одеська, Рівненська, Харківська, Чернівецька, } \\
\text { Чернігівська, м.Київ }\end{array}$ \\
\hline & $\begin{array}{l}\text { Фінансування внутрішніх } \\
\text { витрат на виконання наукових } \\
\text { досліджень }\end{array}$ & $\begin{array}{c}\text { Вінницька, Волинська, Дніпропетровська, Житомирська, Закарпатська, } \\
\text { Запорізька, Івано-Франківська, Київська, Кіровоградська, Луганська, } \\
\text { Львівська, Миколаївська, Одеська, Полтавська, Рівненська, Сумська, } \\
\text { Тернопільська, Харківська, Херсонська, Хмельницька, м.Київ } \\
\end{array}$ & Донецька, Черкаська, Чернігівська, \\
\hline & $\begin{array}{l}\text { Кількість аспірантів, що } \\
\text { виконують науково-дослідні } \\
\text { роботи }\end{array}$ & $\begin{array}{c}\text { Закарпатська, Запорізька, Сумська, Тернопільська, Хмельницька, } \\
\text { Чернівецька }\end{array}$ & $\begin{array}{c}\text { Вінницька, Волинська, Дніпропетровська, Донецька, Житомирська, Івано- } \\
\text { Франківська, Київська, Кіровоградська, Луганська, Львівська, } \\
\text { Миколаївська, Одеська, Полтавська, Рівненська, Харківська, Херсонська, } \\
\text { Черкаська, Чернівецька, Чернігівська, м.Київ }\end{array}$ \\
\hline & $\begin{array}{l}\text { Кількість докторантів, що } \\
\text { виконують науково-дослідні } \\
\text { роботи }\end{array}$ & $\begin{array}{l}\text { Закарпатська, Запорізька, Івано-Франківська, Київська, Кіровоградська, } \\
\text { Львівська, Миколаївська, Полтавська, Тернопільська, Чернігівська, }\end{array}$ & $\begin{array}{c}\text { Вінницька, Волинська, Дніпропетровська, Донецька, Житомирська, } \\
\text { Луганська, Одеська, Рівненська, Сумська, Харківська, Херсонська, } \\
\text { Хмельницька, Черкаська, Чернівецька, м.Київ }\end{array}$ \\
\hline \multirow{5}{*}{ 窝 } & $\begin{array}{l}\text { Кількість підприємств, що } \\
\text { займаються інноваційною } \\
\text { діяльністю }\end{array}$ & $\begin{array}{c}\text { Вінницька, Волинська, Дніпропетровська, Донецька, Закарпатська, } \\
\text { Івано-Франківська, Кіровоградська, Луганська, Миколаївська, Одеська, } \\
\text { Полтавська, Сумська, Тернопільська, Харківська, Черкаська, м.Київ }\end{array}$ & $\begin{array}{c}\text { Житомирська, Запорізька, Київська, Львівська, Рівненська, Херсонська, } \\
\text { Хмельницька, Чернівецька, Чернігівська }\end{array}$ \\
\hline & $\begin{array}{l}\text { Кількість впроваджених нових } \\
\text { технологічних процесів }\end{array}$ & $\begin{array}{c}\text { Дніпропетровська, Донецька, Закарпатська, Запорізька, Миколаївська, } \\
\text { Одеська, Сумська, Тернопільська, Харківська, Черкаська, Чернігівська, } \\
\text { м.Київ }\end{array}$ & $\begin{array}{c}\text { Вінницька, Волинська, Житомирська, Івано-Франківська, Київська, } \\
\text { Кіровоградська, Луганська, Львівська, Полтавська, Рівненська, } \\
\text { Херсонська, Хмельницька, Чернівецька, } \\
\end{array}$ \\
\hline & $\begin{array}{l}\text { Обсяг реалізованої інноваційної } \\
\text { продукції }\end{array}$ & $\begin{array}{c}\text { Вінницька, Запорізька, Київська, Кіровоградська, Миколаївська, } \\
\text { Херсонська, Черкаська, Чернігівська }\end{array}$ & $\begin{array}{c}\text { Волинська, Дніпропетровська, Донецька, Житомирська, Закарпатська, } \\
\text { Івано-Франківська, Луганська, Львівська, Одеська, Полтавська, } \\
\text { Рівненська, Сумська, Тернопільська, Харківська, Хмельницька, } \\
\text { Чернівецька, м.Київ }\end{array}$ \\
\hline & $\begin{array}{l}\text { Кількість впроваджених } \\
\text { інноваційних видів продукції }\end{array}$ & $\begin{array}{c}\text { Житомирська, Київська, Сумська, Харківська, Херсонська, Черкаська, } \\
\text { Чернігівська }\end{array}$ & $\begin{array}{c}\text { Вінницька, Волинська, Дніпропетровська, Донецька, Закарпатська, } \\
\text { Запорізька, Івано-Франківська, Кіровоградська, Луганська, Львівська, } \\
\text { Миколаївська, Одеська, Полтавська, Рівненська, Тернопільська, м.Київ }\end{array}$ \\
\hline & Патенти на винаходи & $\begin{array}{c}\text { Вінницька, Волинська, Запорізька, Івано-Франківська, Київська, } \\
\text { Полтавська, Рівненська, Тернопільська, Чернігівська }\end{array}$ & $\begin{array}{c}\text { Дніпропетровська, Донецька, Житомирська, Закарпатська, } \\
\text { Кіровоградська, Луганська, Львівська, Миколаївська, Одеська, Сумська, } \\
\text { Харківська, Херсонська, Хмельницька, Черкаська, Чернівецька, м.Київ }\end{array}$ \\
\hline
\end{tabular}


Також, практично у всіх спостерігається позитивна динаміка темпів росту кількості впроваджених нових технологічних процесів та інноваційних видів продукції. Що стосується патентів на винаходи, то лідерами у 2017 році є такі регіони як Дніпропетровська (132 од.), Одеська (88 од.), Харківська (203 од.) області та м.Київ (425 од.). Проте, аналізуючи темпи росту цього показника, можна відмітити негативну тенденцію росту кількості патентів на винаходи майже по усіх регіонах держави.

Висновки. Оцінюючи стан інноваційного розвитку регіонів держави слід зауважити, що по більшості із них спостерігаються негативні темпи росту передумов та результатів розвитку інноваційної діяльності (табл.4). Окремі регіони держави неефективно використовують наявні передумови, знижуючи цим самим результати інноваційного розвитку (наприклад, Житомирська, Запорізька, Івано-Франківська, Полтавська, Одеська області). Інші регіони держави, навпаки, маючи незначні потенційні можливості забезпечують високі результати розвитку інноваційної діяльності (Черкаська, Чернігівська, Тернопільська) Водночас, для Дніпропетровської, Львівської, Харківської областей та м.Києва характерно наявність передумов та високих результатів інноваційного розвитку регіону. Отже, така ситуація вимагає застосування диференційованого підходу до вибору напрямів забезпечення інноваційного розвитку регіону залежно від наявних передумов та його результатів.

\section{Список використаних джерел:}

1.Варналій 3. Регіональна інноваційна політика України: проблеми та стратегічні пріоритети // Економіст. - 2007. - № 9. - c. 36-39.

2.Воротін В., Васильців Т., Волошин В. Інноваційний розвиток регіонів як чинник підвищення конкурентоспроможності // Економіст. - 2008. - № 2. - с. 39-40.

3.Денисюк В. Методологія оцінки та аналізу динаміки інноваційної активності промисловості регіону // Економіст. 2006. - № 3. - c. 40-43.

4.Мілевська Т.С. Оцінка інноваційної активності регіону. Бізнесінформ, №4, 2012, С.104-107.

5.Рудь Н.Т. Інноваційний потенціал регіону: нові підходи до оцінки. Регіональна економіка, 2011, №4. С.140-150.

6.Федулова, Л. І. Інноваційна економіка [Текст] : підручник / Любов Іванівна Федулова.-К.: Либідь, 2006. (Навчальне видання).

7.Федулова Л.І. Тенденції розвитку інноваційної політики та ії вплив на економічне зростання / Л. І. Федулова // Економіка і прогнозування. - 2011. - № 2. - С. 63-81.

8.Концептуальні засади формування інноваційної системи підприємств / Л. І. Федулова // Актуальні проблеми економіки. - 2014. - № 10. - С. 195-205.

9.Статистичний збірник. Наукова та інноваційна діяльність України. К, 2018, 178 с.

10. Статистичний збірник. Наукова та інноваційна діяльність України. К, 2016, 257 с

11. Ковальська Л.Л. Конкурентоспроможність регіону: теорія, методологія, практика / Герасиимчук 3.В., Ковальська Л.Л. // Монографія. - Луцьк.: ЛНТУ, 2008. - 280 с.

12. Ковальська Л.Л. Оцінка конкурентоспроможності регіону та механізми їі підвищення: Монографія. - Луцьк: Надстиря, 2007. - 420 